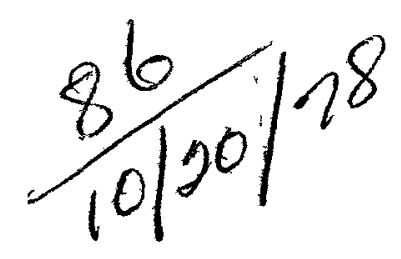

THIS DOCUMENT IS NOT TO BE FURTHER DISSEMINATED WITHOUT THE EXPRESS WRITTEN CONSENT OF THE

DIRECTOR, FUEL CYCLE PROGRAM OFFICE

\title{
CRITICALITY RESEARCH IN SUPPORT OF CHEMICAL REPROCESSING IN THE THORIUM FUEL CYCLE TECHNOLOGY PROGRAM-BASIC PROCESS DESCRIPTION
}

\author{
R. A. Libby \\ This document is \\ PUBLICLY RELEASABLE \\ PNNL reView \\ Authorizing Official \\ May 1978 \\ Date $3-12-12$
}

\section{Prepared for the U.S. Department of Energy \\ Fuel Cycle Program Office \\ Under Contract EY-76-C-06-1830}

\section{APPLIED TEEHNOLOGY}

"Any furtherwinwihution by any holder of this document or the data therein to third parties representmug foreign interests, foreign gucernments, foreign cumpanies and foreign subsidtamer foreign divisions of Ur. companies should be wardinated with the Director, videar Power Developmentivision, Department of tinury."

Pacific Northwest Laboratory

Operated for the U.S. Department of Energy

By
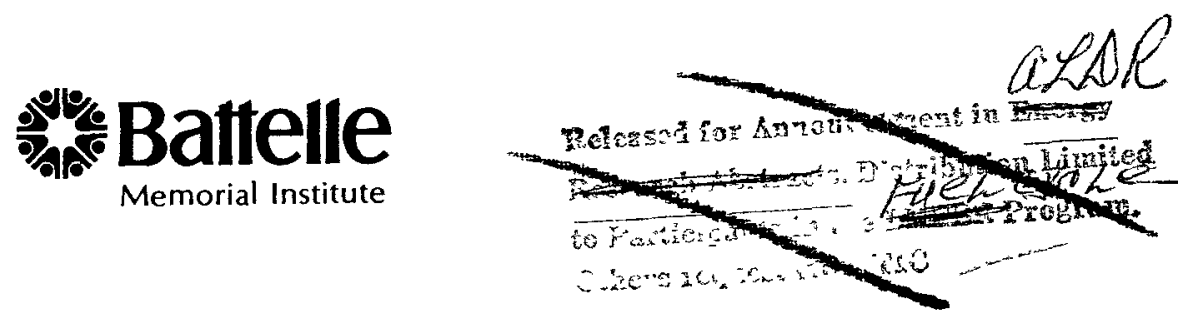


\title{
NOTICE
}

This report was prepared as an account of work sponsored by the United States Government. Neither the United States nor the Department of Energy, nor any of their employees, nor any of their contractors, subcontractors, or their employees, makes any warranty, express or implied, or assumes any legal liability or responsibility for the accuracy, completeness or usefulness of any information, apparatus, product or process disclosed, or represents that its use would not infringe privately owned rights.

The views, opinions and conclusions contained in this report are those of the contractor and do not necessarily represent those of the United States Government or the United States Department of Energy.

\author{
PACIFIC NORTHWEST LABORATORY \\ operated by \\ BATTELLE \\ for the \\ UNITED STATES DEPARTMENT OF ENERGY \\ Under Contract EY-76-C-06-1830
}
Technical Information Center
U.S. Department of Energy
P. O. Box 52
Oak Rıdge, TN 37830

Price: Printed Copv \$4.50; Mıcrofıche $\$ 300$ 


\section{DISCLAIMER}

This report was prepared as an account of work sponsored by an agency of the United States Government. Neither the United States Government nor any agency Thereof, nor any of their employees, makes any warranty, express or implied, or assumes any legal liability or responsibility for the accuracy, completeness, or usefulness of any information, apparatus, product, or process disclosed, or represents that its use would not infringe privately owned rights. Reference herein to any specific commercial product, process, or service by trade name, trademark, manufacturer, or otherwise does not necessarily constitute or imply its endorsement, recommendation, or favoring by the United States Government or any agency thereof. The views and opinions of authors expressed herein do not necessarily state or reflect those of the United States Government or any agency thereof. 


\section{DISCLAIMER}

Portions of this document may be illegible in electronic image products. Images are produced from the best available original document. 
THIS DOCUMENT IS NOT TO BE FURTHER DISSEMINATED WITHOUT THE EXPRESS WRITTEN CONSENT OF THE DIRECTOR, FUEL CYCLE PROGRAM OFFICE
PNL-2080-11

Distribution Category UC-83

CRITICALITY RESEARCH IN SUPPORT OF CHEMICAL REPROCESSING IN

THE THORIUM FUEL CYCLE TECHNOLOGY PROGRAM - BASIC PROCESS DESCRIPTION

R. A. LIBBY

Thus document is

\section{PUBLICLY RELEASABLE}

PNNL review

Authorizing Official

Date. $3-12-12$
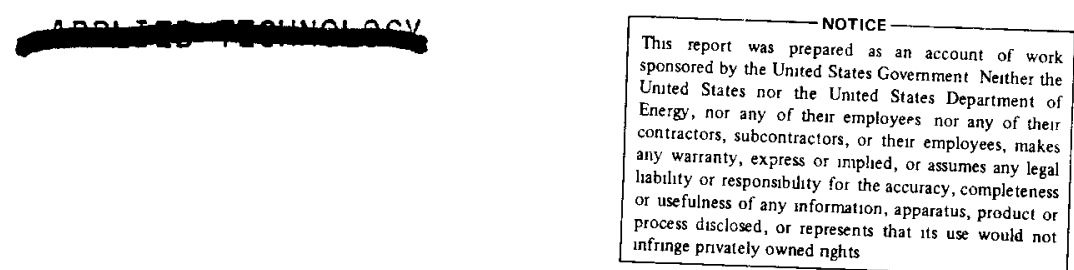

PACIFIC NORTHWEST LABORATORIES

RICHLAND, WASHINGTON 99352

PREPARED FOR THE

OEPARTIAENT OF ENERGY

FUEL CYCLE PROGRAM OFFICE

UNDER CONTRACT EY-76-C-05-1830

Form 189 Number 840.3

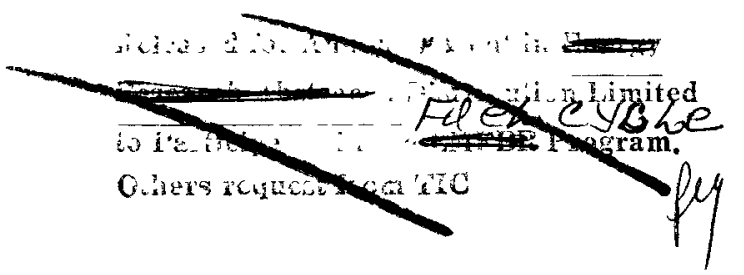


ABSTRACT

The basic processes for reprocessing thorium based light water reactor type fuels are defined for use in identifying criticality data needs. The Reference Thorium Fuel Cycle is used as the primary fuel cycle. Material forms and compositions are described for each major processing step. These forms consist of nitrates and oxides of Th - U - Pu combinations. Fue 1 fabrication and fuel pool storage facilities are aiso defined to the extent they interact with fuel reprocessing. 
TABLE OF CONTENTS

Abstract i

Introduction 1

Process Description 2

Conclusions and Sunmary 11

$\begin{array}{ll}\text { References } & 13\end{array}$

Appendix A - Fuel Fabrication 15

Appendix B - Fuel Reprocessing $\quad 19$

Appendix C - Fuel Isotopic Distributions 21 
CRITICALITY RESEARCH IN SUPPORT

OF CHEMICAL REPROCESSING IN

THE THORIUM FUEL CYCLE TECHNOLOGY

PROGRAM - BASIC PROCESS DESCRIPTION

\section{INTRODUCTION}

In the design and operation of fuel reprocessing olants, a sound understanding of the criticality parameters involved is required to acnieve a safe and economical facility. The purpose of this document is to establish a basic process description for use in identifying criticality data needs in the thorium based Light water Reactor (L'NR) type fuels.

Several fuel cycle options are currently being considered for these thorium based fuels. (1) Practically all combinations of $235_{\mathrm{U}}, 238_{\mathrm{U}}, 233_{\mathrm{U}}$, $P U$, and Th are covered in these various options. As the initial basis for establishing the criticality data needs in these fuel cycles, the Reference Thorium Fuel cycle ${ }^{(1)}$ has been chosen and is the primary fuel cycle considered in this document. 


\section{PROCESS DESCRIPTION}

The flow diagram for the proposed Reference Thorim Fuel Cycle ${ }^{(1)}$ is shown in Figure 1. The fuel cycle consists of six different types of facilities. These are:

- A - Uranium and Thorium mines

- B - Uranium Enrichment Plant

- C - Fuel Fabrication Facilities

- D - Light Water Reactors

- E - Spent Fuel Storage Facilities

- F - Chemical Reprocessing Plants

The top row of biocks in Figure 1 represent the present !WR fuel cycle. The facilities indicated in the additional blocks are needed to implement a conplete thorium based fuel cycle. Although this document is primarily concerned with chemical reprocessing plants, fuel fabrication and fuel storage facilities are also covered because of their close interactions with fuel reprocessing.

The fuel fabrication plants include both remote operations, for recycled thorium/uranium (C3) and plutonium/thorium (C4) fuel, and contact operations for non-recycled thorium/uranium fuel (C2). Currently, an oxide fuel form is the primary candidate for the thorium based fuels because of the greater experience with oxide fuel irradiation. The oxide form could be either as a sintered powder or as compacted microspheres. 


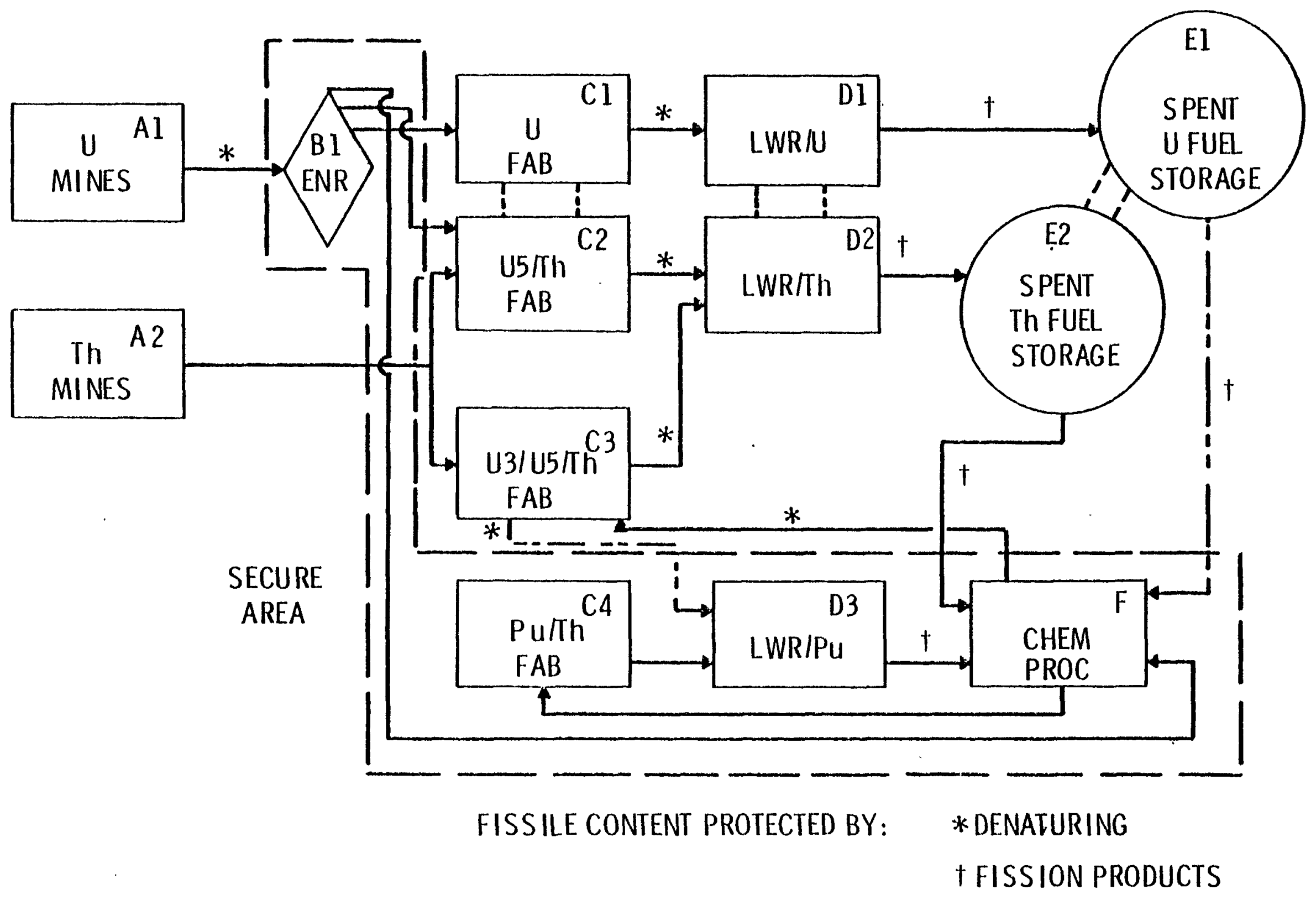


A typical flow sheet for fabricating LWR sintered oxide fuel pellets is shown in Figure 2. (2) A flow sheet for the Oak Ridge Sol-gel process for microsphere fuel fabrication is shown in Figure 3. (3) The sol-gel oxide production process could be located either in the fabrication plant or reprocessing facility. The flow sheet for this process is shown in Figure 4 . (3) The fissile material form at various process steps for fuel fabrication and sol-gel preparation are presented in Appendix A.

The criticality safety limits placed on spent fuel storage pools at reactor sites or in facilities dedicated to storage are similar to those which could be used in the storage pool of a chemical reprocessing plant. The reprocessing plants in the referenced fuel cycle ( $F$ in Figure 1 ) must have the capability for reprocessing thrse types of fuel; uranium, uranium/ thorium mixtures, and plutonium/thorium mixtures. Although one plant could be built to handle all fuels, equipment designed for thorex solvent extraction will not be optimum for Purex operation, and vice versa. All fuels will be considered to contain uranium, plutonium, and thorium. A flow diagram for uranium/plutonium/thorium reprocessing is shown in Figure 5. (2) The solvent extraction employs the acid thorex process. A concaptual flowsheet for this process is given in Figures 6 and 7 . The fissile material form at various process steps for reprocessing are presented in Appendix $B$. 


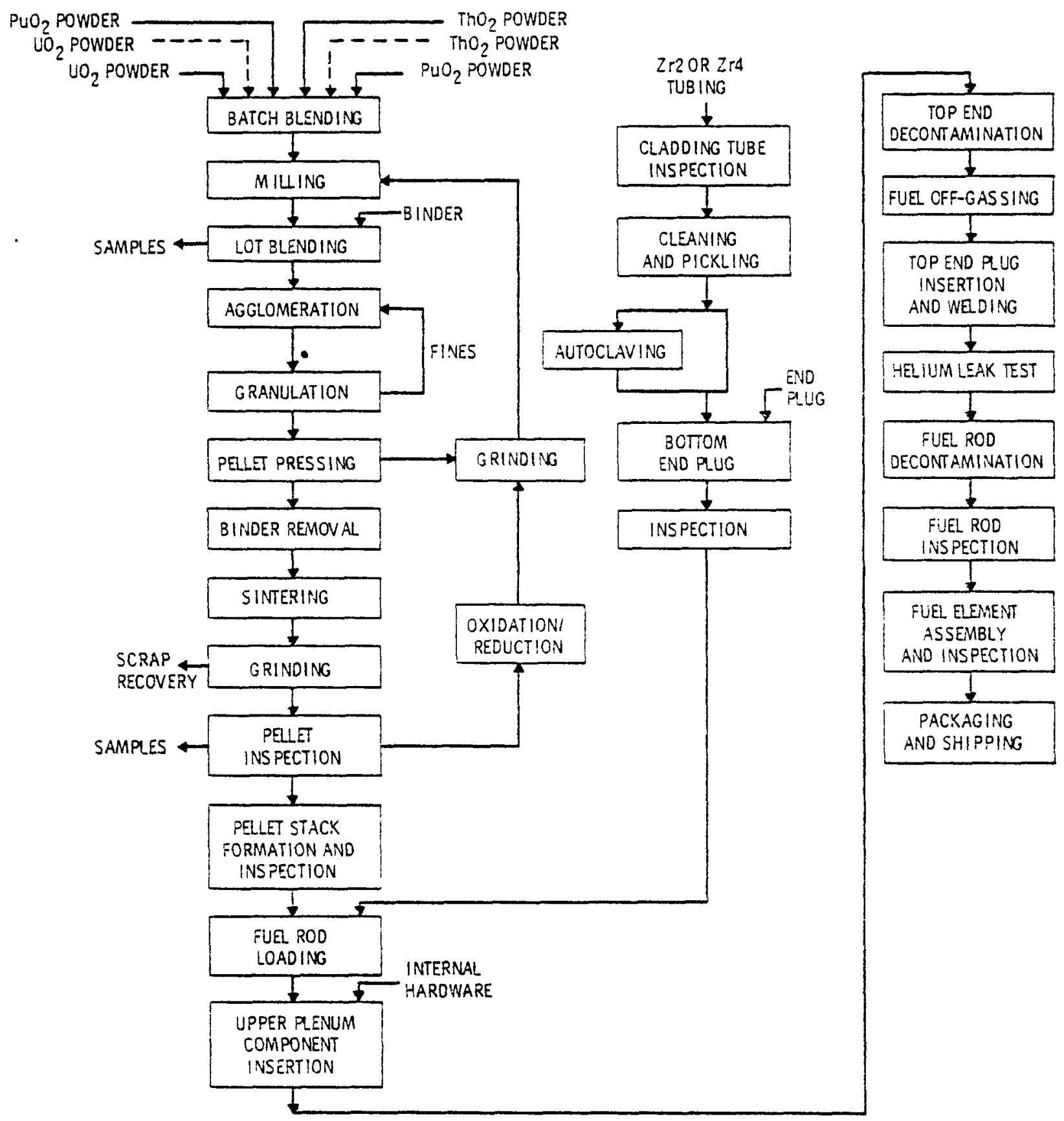

FIGURE 2. Oxide Pellet Fuel Element Fabrication(2) 


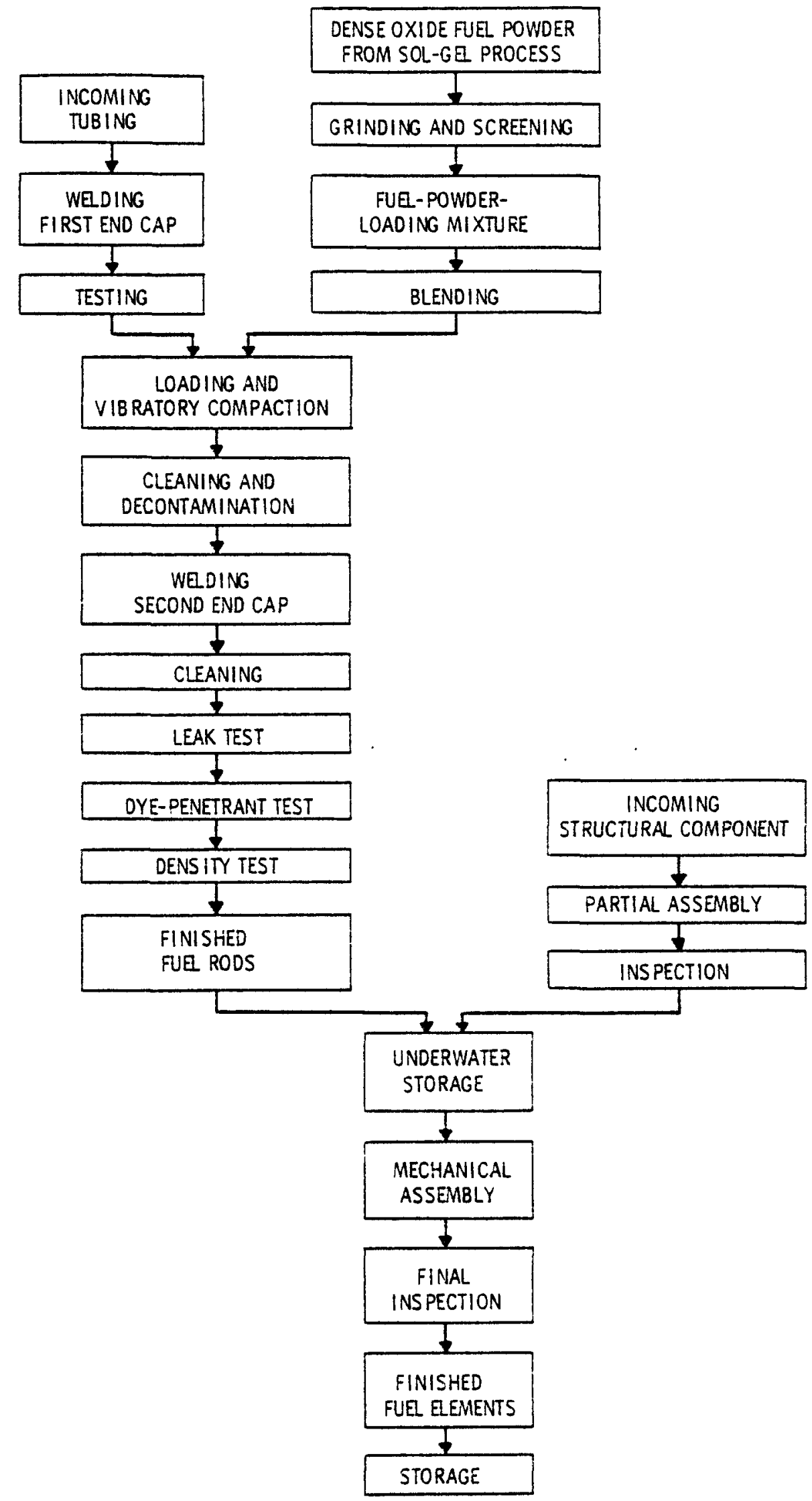

FIGURE 3. SOT-gel Fuel Element Fabrication (3) 


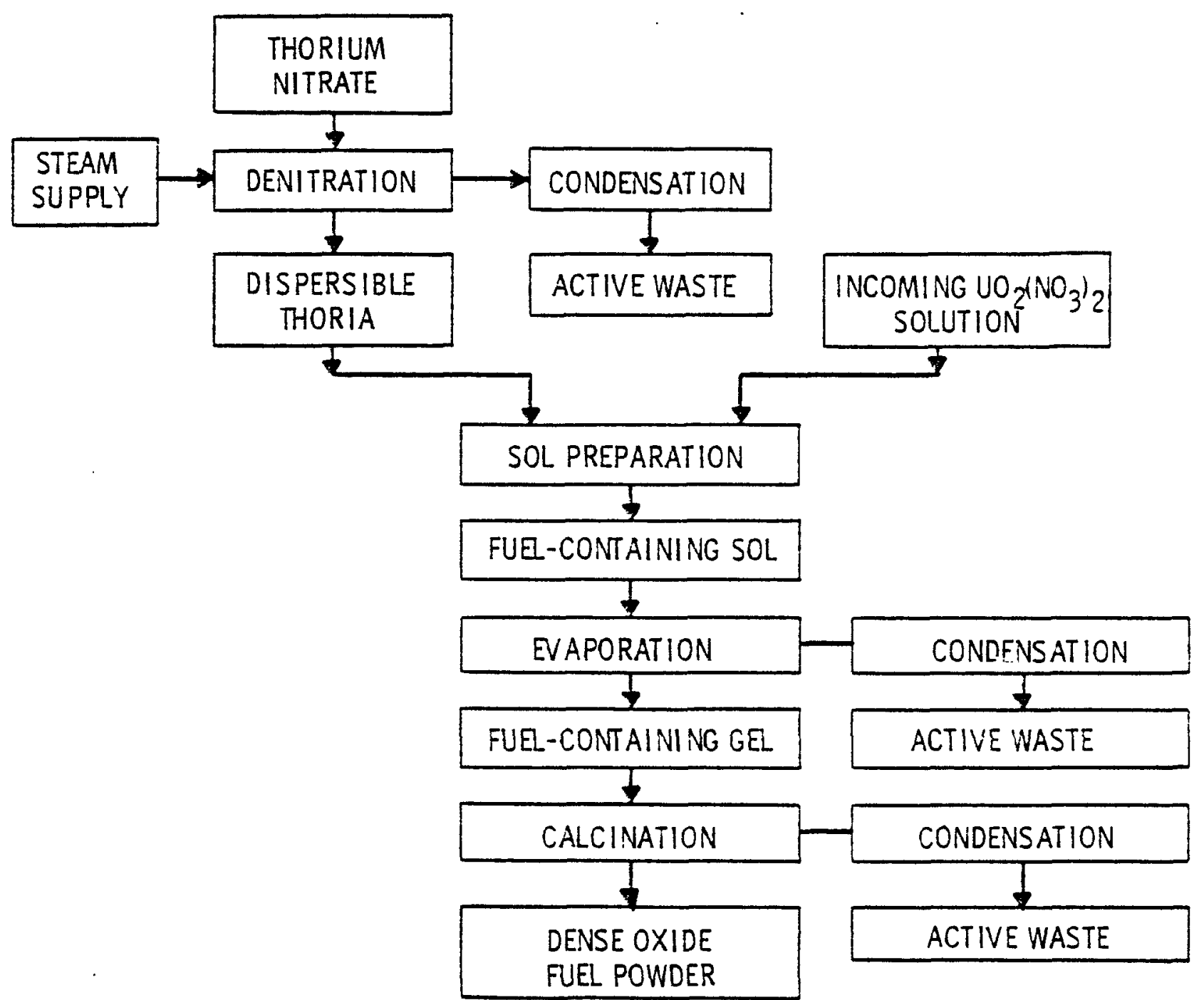

FIGURE 1. SOl-Gel Microsphere Preparation (3) 


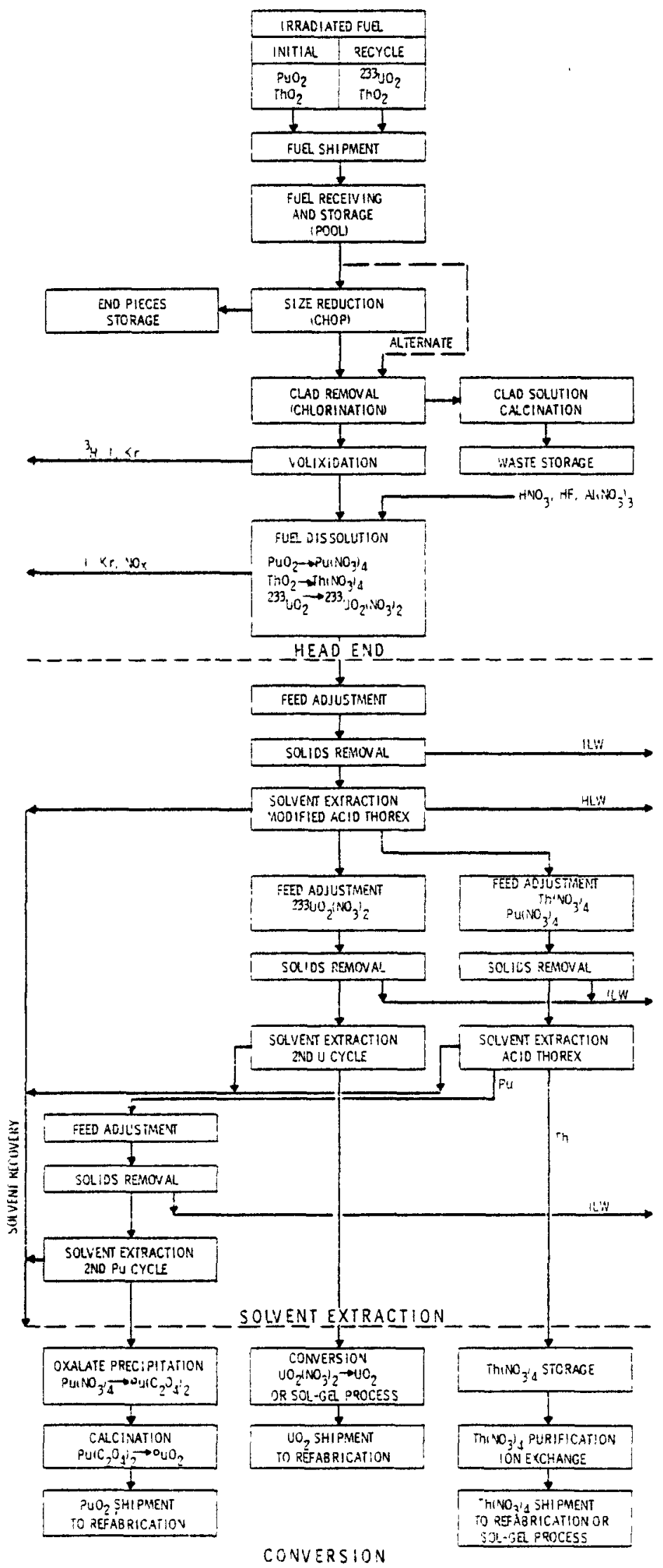




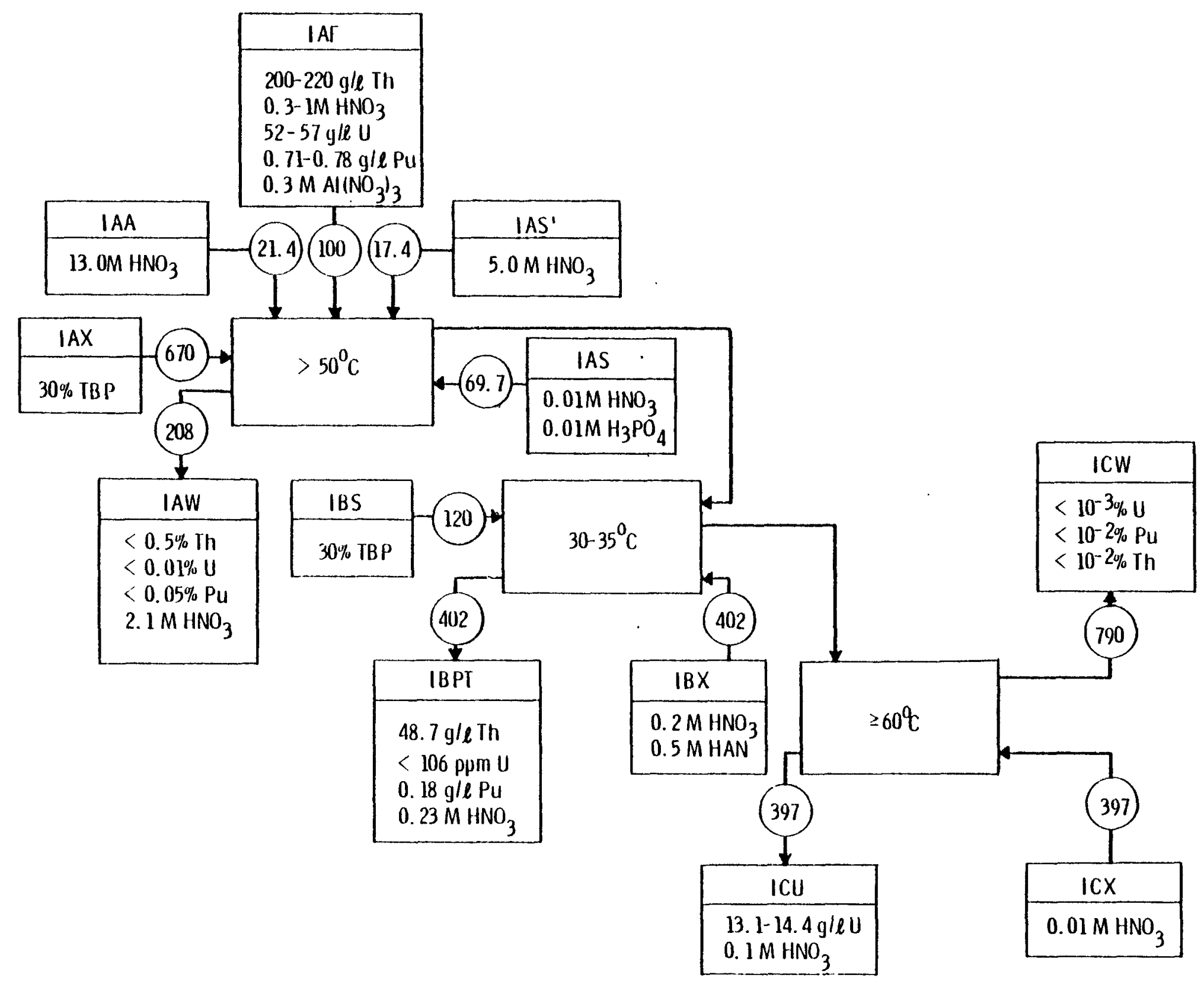




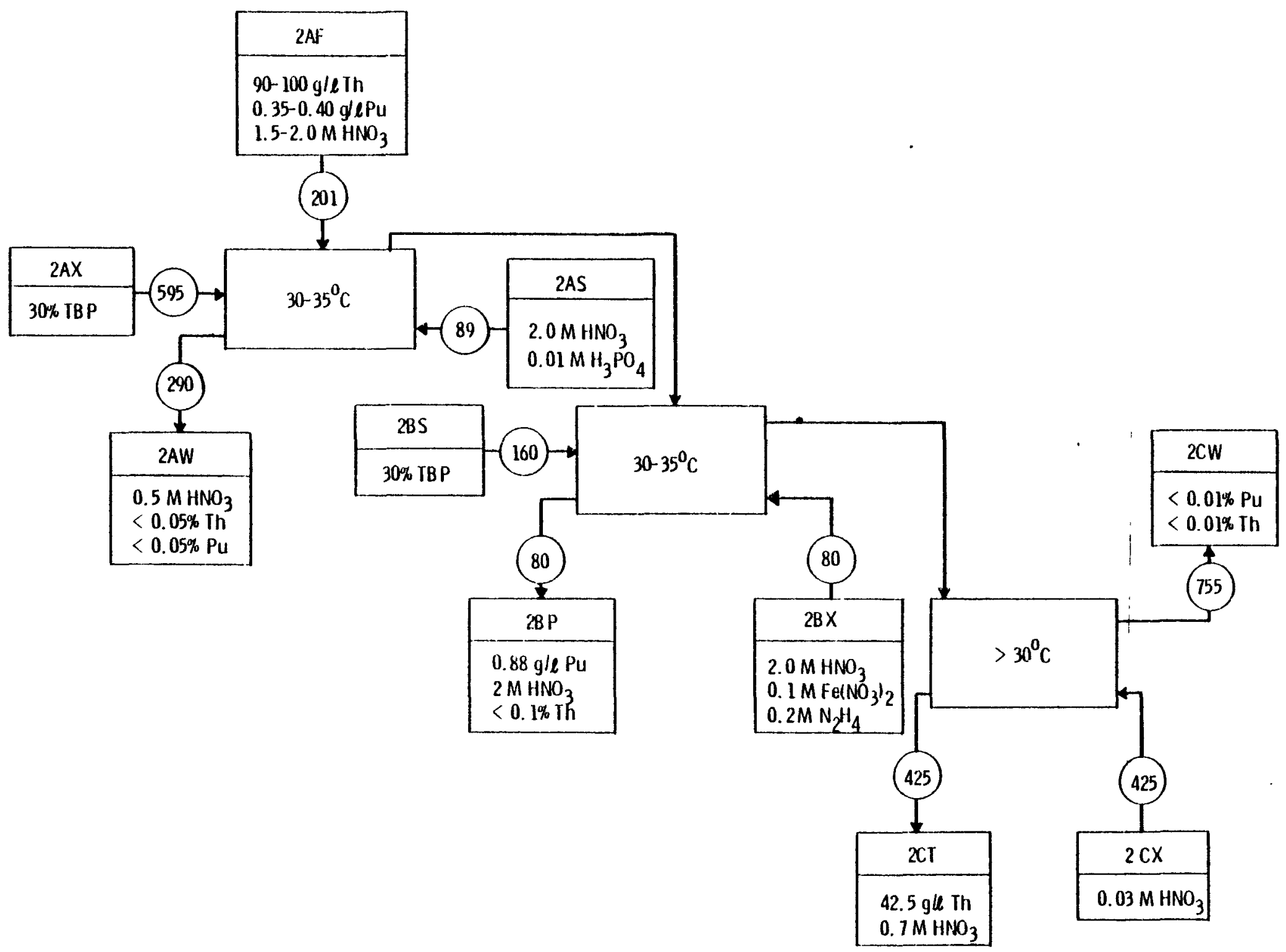

EIGURE 7. Acid Thorex - Second Th/Pu Cycle 
Estimated isotopic compositions for uranium/thorium and plutonium/ thorium fuel cycles are given in Appendix $C$. These abundances are given only to indicate ranges of concentration ratios which might be expected in the fabrication and reprocessing facilities.

\section{CONCLUSIONS AND SUMMARY}

The TFCT program involves a wide range of fuel forms. These include powders, solutions, pellets, rods and fuel rod bundles. Chemical forms include nitrates and oxides. A summary of the expected forms is given below:

- Powders $-\mathrm{UO}_{2}-\mathrm{ThO}_{2}$ and $\mathrm{PuO}_{2}-\mathrm{ThO}_{2}$ powders with low and medium moderation: Possible feed material in fuel fabrication and end product in reprocessing.

- Pellets $-\mathrm{UO}_{2}-\mathrm{ThO}_{2}$ and $\mathrm{PuO}_{2}-\mathrm{ThO} \mathrm{O}_{2}$ both dry and water moderated:

Present fuel fabrication and possibly in head end of reprocessing.

- Rods \& Fuel Rod Bundles - $\mathrm{UO}_{2}-\mathrm{ThO}_{2}$ and $\mathrm{PuO}_{2}-\mathrm{ThO}_{2}$ with and without fixed and soluble poisons: Present in shipping containers, fuel fabrication, and spent fuel storage pools.

- Fuel Rods in Fissile Solution $-\mathrm{UO}_{2}-\mathrm{ThO}_{2}$ and $\mathrm{PuO}_{2}-\mathrm{ThO}_{2}$ mixtures in acid fissile solutions: Present in dissolvers. Rods may be clad or unclad and soluble poisons may be present. 
- Solutions - $\mathrm{UO}_{2}\left(\mathrm{NO}_{3}\right)_{2}-\mathrm{Th}\left(\mathrm{NO}_{3}\right)_{4}$ and $\mathrm{Pu}\left(\mathrm{NO}_{3}\right)_{4}-\mathrm{Th}\left(\mathrm{NO}_{3}\right)_{4}$ solutions: Present in solvent extraction. Possibility of soluble poisons being present. Both over- and under-moderated systems possible. Organic and acid present.

- Fluidized Bed $-\mathrm{UO}_{2}\left(\mathrm{NO}_{3}\right)_{2}-\mathrm{Th}\left(\mathrm{NO}_{3}\right)_{4}$ with trace plutonium present in fluidized bed. The bed may consist of oxide or stainiess steel spheres coated with sprayed $\mathrm{Th}\left(\mathrm{NO}_{3}\right)_{4}$. Normally only depleted uranium is present, but should the solvent extraction system fail, greater than trace quantities of $\mathrm{Pu}$ and $U$ could be present.

All the above uranium/thorium mixtures contain ${ }^{238_{U}}$ with either $235_{U}$ or $233_{U}$ and ${ }^{235} \mathrm{U}$. Criticality data are needed on all these fuel forms to achieve the safest and most economical thorium based LWR fuel cycle. 


\section{REFERENCES}

1. F. E. Driggers, Reference Thorium Fuel Cycle. DPST-TFCT-77-101, E. I. Dupont de Nemours and Company, Savannah River Laboratory, Aiken, South Carolina $29801,1977$.

2. P. R. Kasten, F. J. Homan, et. a1., Assessment of the Thorium Fuel Cycle in Power Reactors. ORNL/TM-5565, Oak Ridge National Laboratory, Cak Ridge, TN, 1977.

3. G. Schileo, "An Unshielded Pilot Plant for Recycling 233 U." In: Thorium Fuel Cycle, CONF-560524 Clearinghouse for Federal Scientific and Technical Information, Springfield, Virginia 22151, 1968.

4. C. C. Haws, J. L. Matherne, F. W. Miles and J. E. Van Cleve, Summary of the Kilorod Project. A semiremote $10-\mathrm{kg} /$ Day Demonstration of $23 \mathrm{UUO}_{2}-\mathrm{ThO}_{2}$ FuelElement Fabrication by the ORNL Sol-Gel Vibratory-Compaction Method. ORNL-3631, Oak Ridge Nationai Laboratory, Oak Ridge, TN, 1965.

5. J. H. Goode, G. Bailije, and J. W. Uliman, Demonstration of the Zirflex and Sulfex Decladding Processes and a Modified Purex Solvent Extraction Process, Using Irradiated Zircaloy-2 and Stainless-Steel-Clad Urania Specimens. ORNL-3404, Oak Ridge National Laboratory, Oak Ridge, TN, 1963.

6. J. H. Goode and J. R. Flanary, Dissolution of Irradiated, Stainless-SteelClad $\mathrm{ThO}_{2}-\mathrm{UO}_{2}$ in Fluoride-Catalyzed Nitric Acid Solutions: hot-cell studies on Pelletized, Arc-Fused, and Sol-Gel-Derived Oxides, ORNL-3725, Oák Ridge National Laboratory, Oak Ridge, TN, 1965.

7. N. L. Shapiro, J. R. Rec, R. A. Matzie, Assessment of Thorium Fuel Cycles in Pressurized Water Reactors. EPRI NP-359, C-E Power Systems, Combustion Engineering, Inc., Windsor, Connecticut 06095, 1977. 
APPENDIX 
APITHIDIX $A-$ IUEL TABPICATION

I. Oxide pellet Fuel Fabrication

Process step

1. Receipl and Storage of $\mathrm{HO}_{2}, \mathrm{HhO}_{2}$, and/or $\mathrm{PuO}_{2}$ ?

\section{ruel cycle rype. \\ us/7h}

$113 / 05 / \mathrm{Th}$

dry Th $_{2}$ powder with trace

quantities of plutonium(a) and uranicum

$\mathrm{Pu} / \mathrm{ih} \quad \mathrm{dry} \mathrm{PuO}_{2}$ powder

dry $\mathrm{ThO}_{2}$ powder $(\mathrm{a})$

2. Blending, Milling,

Aggloneration of axide

powders

$115 / \mathrm{Th}$ or $133 / \mathrm{US} / \mathrm{Th}$

Mixtures of $\mathrm{HO}_{2}$ and $\mathrm{ThO}_{2}$ powders $(\mathrm{a})^{-}$
combined with $\mathrm{binder}$
Mixtures of $\mathrm{PuO}_{2}$ and $\mathrm{ThO}_{2}$ powders

combined with binder

$\mathrm{UO}_{2}-\mathrm{ThO}_{2}$ pellels - normally dry will possibility of moderation trace
3. Pellet messing, sintering, yrindim, inspection, stordye 45/7h or $113 / 145 /$ in

$\mathrm{Pu} / \mathrm{Th}$

$$
\mathrm{Pu} / \mathrm{lh}
$$

(1) or $113 / 15 / \mathrm{in}$
$\mathrm{PuO}_{2}-\mathrm{ThO}_{2}$ pellets - normally dry with mssibility of moderation

(a) Should solvent extraction fall, significant roncentrations of plutonium and/or uranium could be present in recycle thorium. 


\section{APPERDIX A - TUEL TABRICATIOM}

Process step

4. Fuel rod loading, off-gassing, welding, inspection, packaging, storage, shipping.
Fuel Cycle Type

U5/Th or U3/U5/Th
Fissile Material Form

Normally dry rods containing pellets of $\mathrm{Un}_{2}-\mathrm{ThO}_{2}$. Possibility of moderation.

flormd lly dry rods containing pellets

of $\mathrm{PuO}_{2}-\mathrm{ThO}_{2}$. Possibility of moderation.
J. Scrap Recovery; dissolution, precipitation, centrifuging, calcination.
U5/Th, U3/U5/Th, and/or

P'I/Th

Steus similar to reprocessing plant:

Scrap dissolved and thorium, uranium, and plutonium separated. The uranium and plutonium will be orecipitated and calcined to obtain oxide powders for reintroduction at top of flow.

11. Sol-gel Fuel [lement Fabrication

The lissile material forms encountered in sol-gel fuel element faluricalion are similar to those for oxide pellet fuel element fabication except no pellets are producel. Instead, the powder is directly vibralory compacted into the fuel elements. Hence, all fissile material forms except nellets are present. 


\section{APPCINIIX A - IUII IABRICATION}

(6) ORNL-3681

III. Sol-Gel Microsphere Preparalion (4)

Process Step

1. Receipt and storage of $110_{2}\left(\mathrm{NO}_{3}\right)_{2}$ U5/Th and $7 \mathrm{~h}\left(\mathrm{NO}_{3}\right)_{4}$ from puriticalion.

?. Dentration
$\mathrm{U} 3 / \mathrm{US} / \mathrm{Th}$

ruel Cycle Type

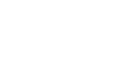

U5/111

11.3/45/71!

\section{Fissile Material Form}

$\mathrm{UO}_{2}\left(\mathrm{NO}_{3}\right)_{2}$ solution only
$\mathrm{UO}_{2}\left(\mathrm{NO}_{3}\right)_{2}$ solutions Th $\left(\mathrm{NO}_{3}\right)_{4}$ containing trace quantities of tissile uranium and plutonium. (a)

None

Recycle Th $\left(\mathrm{NO}_{3}\right)_{4}$ with trace quantities of fissile uranium and plutonium. (a) Product is $\mathrm{ThO}_{2}$. Fluidized bed denicration consists of $\mathrm{Th}\left(\mathrm{NO}_{3}\right)_{4}$ sprayed onlo oxide or staintess steel sphere's. Air jels remove solidified nxide.

3. Sol preparation

U5/Th or U3/U5/Th

Mixtures of $\mathrm{HO}_{2}\left(\mathrm{NO}_{3}\right)_{2}$ and $\mathrm{ThO}_{2} \mathrm{i}_{\text {a }}$ Trace plutonium may be present. (a) Product $\mathrm{UO}_{3}-\mathrm{ThO}_{2}$ sol.

(a) should solvent extraction lail, significant concentrations of plutonium and/or uranium could be present in recycle thorium. 


\section{APPCNDIX A = FUEL FABRICATION}

Process Step

4. Gelation and Calcination
Tuel Cycle Tyne

$1 / 5 / T h$ or $133 / 115 / \mathrm{Th}$

\section{Fissile Material Form}

$\mathrm{NO}_{3}-\mathrm{Th} \mathrm{O}_{2}$ is evaporated and calcined. Product is dense, dry $1100_{2}-\mathrm{ThO}_{2}$ (a)

(a) Should solvent extraction fail, significant concentrations of plutonium and/or uranium could be present in recycle thorium. 


\section{APPENDIX B - FIIFL RTPROCESSING}

I. Uranium/Thoritun Fuel Reprocessing (Both 115/Th and 113/115/Th)

\section{Process Step}

1. Receipt and storage of $\mathrm{HO}_{2}-\mathrm{Th}_{2}$ irradiated fuel elements.

\section{Tissile Material Form}

$235 \mathrm{HO}_{2} / 7 \mathrm{hO}_{2}$ and $233 \mathrm{HO}_{2} / \mathrm{ThO}_{2}$ rods in bundles. Probably stored in water basins.
2. Chopping of fuel rods and clad removal by zirflex and sulfex. ${ }^{(5)}$

Ilry $\mathrm{U}_{2} / \mathrm{ThO}_{2}$ rods and mixtures of rods in acid solution with oxide fines. Zircaloy clad relloval in boiling $6 \mathrm{MIN}_{4} \mathrm{~F}-1 \mathrm{MNI}_{4} \mathrm{NO}_{3}$. Stainless steel clad removal refluxing $\mathrm{III}_{2} \mathrm{SO}_{4}$.

Oxidation heating to cause $10_{2}$ change to $\mathrm{U}_{3} 0_{8}$.

3. Voloxidation to remove volatile tission products and tritiun.

4. Dissolving (6)

1.1.
Change of $\mathrm{HO}_{2}$ to $\mathrm{IO}_{2}\left(\mathrm{NO}_{3}\right)_{2}$ and $\mathrm{ThO}_{2}$ to $\mathrm{Th}\left(\mathrm{NO}_{3}\right)_{4}$ in solution of ${ }^{12 \mathrm{M}}-\mathrm{HHO}, 0.05 \mathrm{M} \mathrm{HF}$ and $\mathrm{AI}\left(\mathrm{NO}_{3}\right)_{2}$. Rods and fissile solutions will be present simultaneously. Also, soluble poisons might be present. low concentrations of plutonium are also present. 


\section{APPENDIX B - IULL RI PROCESSING}

\section{Process Step}

5. First Cycle solvent extraction.

6 Second cycle solvent extraction $(\mathrm{Th} / \mathrm{Pu})$.

\section{fissile Material Form}

$200-220 \mathrm{~g} / \mathrm{e}$ Th with $52-57 \mathrm{~g} / \mathrm{e} \mathrm{I}$ and $0.71-0.78 \mathrm{~g} / \mathrm{Pu}$ feed. Also present $11 N_{3}$ and $30 \% \mathrm{TBP}$. Fixed poisons may be present. $90-100 \mathrm{~g} / \mathrm{x}$ Th with 0.35 to $0.4 \mathrm{~g} / \mathrm{x} \mathrm{Pu}$ in $1 / 5-2.0 \mathrm{M} \mathrm{HNO}_{3}$, Trace $\mathrm{U}$. Fixed poisons llay be present.

7. Second cycle solvent extraction Over moderated $\mathrm{HO}_{2}-\left(\mathrm{NO}_{3}\right)_{2}$ solution with trace $\mathrm{Th}$ and $\mathrm{Pu}$. (u).

8. $\mathrm{UO}_{2}\left(\mathrm{NO}_{3}\right)_{2}$ conversion or transfer $\mathrm{HO}_{2}\left(\mathrm{HO}_{3}\right)_{2}$ solution converted to either $\mathrm{UF}_{6}$ or $\mathrm{HO}_{2}$. to sol-gel facility.

9. Th $\left(\mathrm{NO}_{3}\right)_{4}$ purification and ship- Th $\left(\mathrm{NO}_{3}\right)_{4}$ with trace Pu content. ment to refabrication or sol-yel facility.

10. Pu conversion $\mathrm{Pu}\left(\mathrm{NO}_{3}\right)_{4}$ converted to $\mathrm{Pu}\left(\mathrm{C}_{2} \mathrm{O}_{4}\right)_{2}$ allet then to $\mathrm{Pu} \mathrm{O}_{2}$.

II. Plutonium/Thorium Fuel Reprocessing

The reprocessing of plutonium/thorium fuel is similar to uranium/thorium fuel. The difference is in the abundances for uranium and plutonium. Similar process steps are employed. Appendix $C$ gives estimated isotopic concentrations.

(a) Should second Th-Pu cycle solverit extraction fail, significant Pu could result. 
APPENDIX C

Apcendix C

FUE ISOTOPIC DISTRIBUTIONS

Fuel Compositions (wt:\%)

\begin{tabular}{|c|c|c|}
\hline U5/Th Fuel ${ }^{(1)}$ & Initial Load & $\begin{array}{l}\text { Irradiated } \\
(29,000 \mathrm{Mll} / \mathrm{Mt})\end{array}$ \\
\hline Th & 0.7785 & 0.7910 \\
\hline $235, y$ & 0.0443 & 0.0179 \\
\hline $238 U$ & 0.1772 & 0.1769 \\
\hline $233 U$ & - & 0.0108 \\
\hline Fissite Pu & - & 0.0028 \\
\hline
\end{tabular}

\begin{tabular}{|c|c|}
\hline U3/U5/Th Fuel (2) & Pecycle Luad \\
\hline Th & $0.708-0.7785$ \\
\hline $235_{U}$ & $0.0-0.0443$ \\
\hline $238 v$ & $0.1772-0.57$ \\
\hline $233_{v}$ & $0.0-0.035$ \\
\hline
\end{tabular}

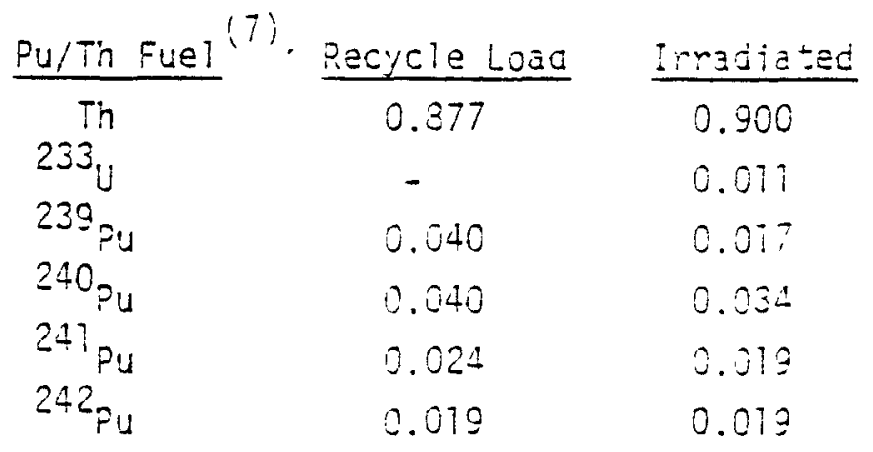




\section{.}




\section{DISTRIBUTION}

No. of

Copies

\section{OFFSITE}

1 A. A.Churm DOE Patent Group $9800 \mathrm{~S}$. Cass Avenue Argonne, IL 60439

1 Mr. T. B. Hiridmän, Jr., Director

Fuel Cycle Programs office

Savannah River Operations Office

P. 0. Box A

Aiken, SC 29801

3 Dr. Joe Spencer

Savannah River Laboratory

E. I. du Pont de Nemours and Company

Aiken, SC 29801

100 Technical Information Center

\section{ONSITE}

\section{Pacific Northwest Laboratory}

T. A. Ambrose

S. R. Bieman

C. L. Brown

iv. E. Carter

E. D. Clayton

W. E. Converse

B. M. Durst

L. C. Davenport

D. E. Friar

B. F. Gure

O:F. Hill

3. W. Howes

U. P. Jenquin

B. R. Leonard

R. A. Liboy (10)

R. C. Lloyd

J. S. McPherson

D. F. Newman

D. R. Oden

D. E. Oiesen

T. i. Trapp
No. of

Copies

Pacific Northwest Laboratory (contd)

Technical information (5)

Publishing Coordination (2)

\section{ONSITE}

2 Richland Operations

\section{P. A. Craig}

H. E. Ransom 